January 2013

\title{
Using Technology to Connect Public Libraries and Teens
}

Susan M W Aplin

San Jose State University, susanaplin@gmail.com

Follow this and additional works at: https://scholarworks.sjsu.edu/ischoolsrj

Part of the Library and Information Science Commons

\section{Recommended Citation}

Aplin, S. M. (2013). Using Technology to Connect Public Libraries and Teens. School of Information Student Research Journal, 2(2). https://doi.org/10.31979/2575-2499.020207 Retrieved from https://scholarworks.sjsu.edu/ischoolsrj/vol2/iss2/7

This article is brought to you by the open access Journals at SJSU ScholarWorks. It has been accepted for inclusion in School of Information Student Research Journal by an authorized administrator of SJSU ScholarWorks. For more information, please contact scholarworks@sjsu.edu. 


\title{
Using Technology to Connect Public Libraries and Teens
}

\begin{abstract}
Today's teens use technology in most aspects of their lives: $95 \%$ of teens go online; $80 \%$ of online teens use social media (Lenhart et al., 2011); and $87 \%$ of older teens have a mobile phone (Lenhart, 2012). This article explores how public libraries can use technology to effectively connect with and serve their young adult patrons. A review of current literature suggests that librarians begin by involving teens in the planning of young adult services and teen library spaces. These services should include librarians trained in working with teens as well as access to technology and gaming. Libraries must understand how and why teens use technology and the Internet. They should then use this knowledge to plan and develop an online presence. Today's librarians should use library websites and social networking sites to connect with teens. In addition, libraries must address other technologies that interest teens such as mobile devices and e-reading. Technology changes rapidly, and librarians must stay current on best practices for reaching out to and serving today's teens.
\end{abstract}

\section{Keywords}

e-reading, gaming, public libraries, technology, teens, websites, social networking sites, mobile, online

\section{About Author}

Susan Aplin has a Bachelor of Arts in English from Pomona College and a Master of Arts in Teaching English from the University of South Carolina. She is a National Board Certified English teacher at Dutch Fork High School in Irmo, SC, where she also serves as a Teacher Technology Leader. Susan completed the original research for this literature review as a part of an Information and Society course at San Jose State University's School of Library and Information Science. 
Today's public libraries must be many things to many people, including the young adults in their communities. In order to best serve teen patrons, libraries should have young adult librarians who focus exclusively on teens, yet many libraries do not provide these specialized positions (Vaillancourt, 2000). Libraries that do not effectively serve teens are missing opportunities to reach an important segment of their local population and to help teens become lifelong users of the library system (Jones, 2003). Teen patrons present challenges for libraries due to their varied interests, changing needs, and short attention spans, but reaching them at this important time in their lives can make both an immediate and a long term difference (Houston, 2011). Libraries can provide teens with places to belong, while at the same time supporting positive behaviors and helping them avoid risky situations (Joseph, 2010; Walter \& Meyers, 2003). For these important reasons, public libraries should make it a priority to reach out to teens and connect their services to these patrons. What follows is a review of current literature by experts in this field. Researchers generally agree that successful teen services begin in the library with good planning, comfortable places that provide access to technology, and effective librarians. It is imperative that today's library services go beyond the physical library and try to reach teens through technology including websites, social networking sites, mobile devices, and e-reading. By using technology in a variety of ways, libraries can better connect with and successfully serve today's teens.

\section{Connecting in Person}

All public libraries have the goal of serving their young adult patrons' informational, recreational, and educational needs, but each library makes its own decisions about how to prioritize those needs (Jones, Gorman, \& Suellentrop, 2004). Researchers agree that an important first step in developing teen library services is to involve young adults in planning (Agosto, 2007; Shay, 2011; Walter $\&$ Meyers, 2003). Giving young adults opportunities to plan services, events, and teen spaces will result in a more vested interest in the libraries (Couri 2011; Macchion \& Savic, 2011). Libraries should conduct surveys and focus groups to better assess teens' needs (Bishop \& Bauer, 2002; Bourke, 2010; Hannan, 2011). In addition, an active teen advisory board can be helpful in planning events (Houston, 2011; Klipper, 2011), advocating for teen programs (Comito \& Escobedo, 2011; Jones et al., 2004), and bringing friends to library events (Bishop

$\&$ Bauer, 2002). Researchers also recommend that libraries provide opportunities for teens to volunteer (Bishop \& Bauer, 2002; Macchion \& Savic, 2011). Youth involvement is so central to the success of young adult services that Jones, Gorman, and Suellentrop (2004) include it as one of six main goals for library planning. 
Librarians can take what they learn from their teen patrons and use it to plan one of the key components of successful teen library programs: inviting library spaces (Bernier, 2009). Libraries should provide young adults with spaces that are just for them, apart from children's sections (Houston, 2011; Nowak, 2011; Sullivan, 2011). Teens need to be directly involved in the planning of those spaces (Bernier, 2009; Howard, 2011). Whether it is just a small area or a completely separate room, an ideal young adult area is welcoming and comfortable. It should be a place where young adults can be themselves and work together (Houston, 2011; Walter \& Meyers, 2003). This often means allowing teens to eat and socialize in this space (Bishop \& Bauer, 2002; Howard, 2011).

This space should also have computers and other technology that appeal to teens, making it a place where teens go not only to read and research, but also to create and share (Van Lewen, 2009). Surveys show that young adults expect to have computer access in the library (Ayar, 2009; Walter \& Meyers, 2003). By also providing free Internet access, libraries can bridge the digital divide and help teens without computers gain access to websites and social networking sites (Jones, et al., 2004). In addition, libraries can help teens by providing the time, space, and digital tools they need to collaborate and create. These digital tools might include cameras, video cameras, and access to software. Cultural anthropologist Mizuko Ito (2008) explains that teens need not only to have digital tools available to them, but also need "a degree of freedom and autonomy for selfdirected learning and exploration" (p. 22). By providing these tools and the space to use them, libraries become valuable resources to teens.

Libraries should also provide training and guidance for teens on the use of technology (Ludwig, 2011). Researchers should investigate the best methods librarians can use to help educate teens about online issues such as cyberbullying, privacy policies, and copyright laws (Agosto \& Abbas, 2011; Lamb, 2011). One possibility would be to offer classes to teens during national Teen Tech Week, a program sponsored by the Young Adult Library Services Association (YALSA) that aims to promote "competent and ethical users of technologies" (Van Lewen, p. 33). Teens enjoy learning from their peers (Ito et al., 2010), so libraries should include teens as partners in their technology training when possible.

In addition to providing the space and digital tools teens need to be creative, as well as guidance on the use of those tools, libraries have opportunities to connect with teens through another incredibly popular form of technology: gaming. According to a 2009 Pew Internet study, 97\% of teens play video games (Lenhart, 2009). Libraries can reach out to more teens if they offer games and gaming events. Teens play a variety of games for many different reasons; today's video games are more social than those of the past (Ito et al., 2010). Focusing on the social aspect of gaming will help libraries be more successful in connecting 
with teens. The Library Game Lab at Syracuse University surveyed 400 public libraries and discovered that "77\% of those libraries . . . supported gaming in some way" (Nicholson, 2008, p. 50).

Including gaming in the public library has benefits for both the library and the teens who participate. First, by hosting gaming events, libraries get teens into the building, which helps teens begin to realize the value of libraries (Jones et al., 2004). These same events give libraries opportunities to promote other services teens might want to use (Macchion \& Savic, 2011). In fact, some libraries have seen "youth who come in for gaming who then show an interest in reading and other library programs" (Van Lewen, 2009, p. 33). Other libraries have seen a general increase in teen traffic, new teens coming to use the library, and more interest in the events being held there (Neiburger, 2007). Also, research has shown that the video games themselves can "promote literacy, critical thinking, [and] problem solving skills" (Hill, 2010, p. 35). Many scholars view gaming as a type of storytelling, and therefore directly tied to promoting literacy (Bolan, Canada, \& Cullin, 2007; Nicholson, 2008). Multi-player videogames also allow teens to socialize with one another and often allow them to explore new identities and realities (Macchion \& Savic, 2011). Teens can gather to play games in much the same way that they might gather for a book club (Danforth, 2011), so these games encourage teens' social interests (Long, 2005). While some might have reservations about whether gaming is a suitable pursuit for libraries, these potential critics should consider all of the other changes libraries have undergone over the years (Neiburger, 2007). If librarians want to connect with teens through activities the teens enjoy, then libraries certainly must include gaming.

In order to facilitate teens' digital creations, gaming events, and any other library activities, libraries must have staff members who are welcoming to all patrons (Bourke, 2010; Jones, et al., 2004). All library staff members should recognize that they serve young adults as well as other patrons, regardless of the staff members' specific library jobs or titles (Houston, 2011). By training staff members to deal effectively with teen patrons, libraries can help build a solid foundation for future library interactions and ensure that teens get the most out of their library experiences (Houston, 2011). Those who work closely with young adult patrons need to be especially patient and approachable and must realize that a positive attitude can be one of the most important factors in developing relationships between teens and librarians (Bourke, 2002; Hannan, 2011; Jones et al., 2004). Librarians can show their interest by getting out from behind the desk (Bolan et al., 2007) and speaking directly to all teens, even those who come into the library with their parents (Vaillancourt, 2000). Young adult librarians should also have other key qualities, such as flexibility, a sense of humor, empathy, and open-mindedness (Vaillancourt, 2000). Librarians must care about their teen patrons, and let the teens know it. Once librarians have established relationships, 
they will be able to "work with [teens] in learning the skills needed for adulthood" (Walter \& Meyers, 2003, p. 41) and "empower [teens] and encourage information literacy and independent thinking" (Jones et al., 2004, p. 272).

\section{Connecting Online}

Librarians must work to establish relationships with teens inside the library building, but librarians must also recognize that many of today's teens are more likely to be online than in a library. If librarians truly want to serve teens, the librarians must reach out and "become integral members of the online community" (Hughes-Hassell \& Miller, 2003, p. 145). Today's teens are "digital natives" who were born into a digital world and have grown up on the Internet (Prensky, 2001, p. 1). They "have been raised and educated in a world where the Internet is taken for granted" (Nowak, 2011, p. 6). Technology is ubiquitous, and teens are used to being immersed in it (Flowers, 2008; Goodstein, 2007). Research shows that today's teens are online more than their predecessors, with 95\% of teens going online (Lenhart et al., 2011). As a result, "It only makes sense that if you want to reach out to this community and forge relationships that foster cooperation, collaboration, understanding, and lifelong learning between the generations, the way to do it is through the Internet" (Peowski, 2010, p. 26). The Internet now offers people more opportunities to connect and interact than ever before. Maintaining a "strong library web presence is no longer optional" (Valenza, 2011, p. 38). If a library wants to serve its teen patrons, it must be available electronically 24/7. Websites have moved beyond static informationgiving pages, and many are now collaborative Web 2.0 sites where both librarians and patrons can participate (Casey \& Savastinuk, 2006). The interactive nature of these sites makes it easier for libraries to connect with today's online teens.

The possibilities for online interactions between teens and libraries are almost limitless. Library websites, social networking sites, and other Web 2.0 resources provide a variety of ways to connect with teens. Before librarians look at specific platforms and options, they should consider their audience: teens in their own communities. Involving them in the planning of any online options will dramatically increase the success of those programs (Peowski, 2010). Just like when planning in-library spaces and services, librarians should talk to teens and ask them what they would like to see the library do online (Peowski, 2010). "If at all possible, teens should be involved with designing the website and choosing the content" (Hilbun, 2011, p. 44). Young adult librarians need to work with their library administrators to determine if it is possible to have teens help with details such as site maintenance and posting content (Hughes-Hassell \& Miller, 2003). For some libraries this is not feasible due to security concerns, but librarians should still be able to get teens' input on choice of platform and type of content. 
Two major challenges facing librarians who wish to create and maintain an online presence are lack of training and lack of time. In a survey of young adult librarians, Hughes-Hassell and Miller (2003) found that "most of the responding librarians described themselves as 'self-taught' Web designers" (p. 151). They concluded that "it is imperative that libraries provide professional development for their staff on Web Design" (Hughes-Hassell \& Miller, 2003, p. 154). If libraries want to connect with teens online, they not only have to provide training, but also provide time to manage the online services (Hilbun, 2011). While other staff members, such as computer specialists, could manage some of the web services, the young adult librarian "needs to be a visible part of these technologies so that teens still feel the personal connection" (Hilbun, 2011, p. 49).

When considering various platforms and online tools, librarians must be mindful of the reasons that most young adults go online. Teens' primary purpose for Internet use is to socialize and make connections (Ito et al., 2010; Jones et al., 2004). As primarily "friendship-driven" users of technology (Ito et al., 2010), today's teens "are concerned about missing out on something important, and they use technology to stay in constant contact" (Lamb \& Johnson, 2006, p. 55). Teens use the Internet (and cell phones) to stay in touch with friends and family, but also to reach out and meet new people (Jones et al., 2004). Teens have discovered that "they can speak and listen to a far more diverse community than they can in their own geographical neighborhoods" (Walter \& Meyers, 2003, p. $53)$.

Teens also go online to figure out who they are and where they fit in; Ito et al. (2010) would call this "interest-driven" use of technology. For many young adults "the Web can be the ideal means for navigating the waters of selfdiscovery" (Rapacki, 2007, p. 28). The Internet provides places for teens to find people more like themselves, while at the same time providing anonymity for those who want it (Goodstein, 2007; Jones et al., 2004). In addition to socializing and identity-searching, teens use the Internet as a source of information and entertainment (Ito et al., 2010). The Internet also provides "opportunities for teens to express themselves and distribute their work" (Goodstein, 2007, p. 13). Libraries must find ways to harness this vast resource both to connect with and to support teens.

Many librarians believe that teens consider themselves to be Internet users before researchers, but Bishop and Bauer (2002) found the opposite to be true. Today's teens do consider themselves researchers, but their methods are different from adults' research. By understanding teens' methods, librarians can help teens become better researchers and guide them to view the library as "a primary access point to information" (Flowers, 2008, p.6). Studies have found that the Internet is the "primary tool" teens use for research, and in one survey "seventy-one percent of teens ... reported that they rely mostly on Internet sources for their research" 
(Hughes-Hassell \& Miller, 2003, p. 144). Many teens turn to Internet sources instead of libraries because they find it easier to locate the information they need (Snowball, 2008). Goodstein (2007) confirmed that teens find online research easier, but also like it because it is faster and they often find more information. Yet teens do not often consider that the information might be unreliable or inaccurate (Goodstein, 2007). Also, "There's no question that students' search skills are generally quite poor," (Jacobs, 2012, n.p.), so librarians must work with teens to help them improve these skills (Bergson-Michelson, 2012; Purcell et al., 2012) and to learn to use libraries as research tools.

Some teens are confused by the variety of search options and do not seem to distinguish between general searches, such as ones using Google, and ones made using online databases (Evanhart \& Valenza, 2004). Students may focus on general searches. For example, a 2012 Pew Internet survey reported that 94\% of teachers surveyed "said that their students were 'very likely' to use Google or other online search engines" (Purcell et al., p. 33). The same study showed the next most popular research tool for students was Wikipedia (Purcell et al., 2012). By helping teens understand the strengths and weaknesses of the various search options, librarians make teens more proficient Internet researchers. Instead of being discouraged by teens' heavy Internet use, librarians need to look at what makes teens turn to the Internet and try to replicate some of those features, such as single box searching, in their own online resources (Nowak, 2011). When librarians understand the appeal of resources like Google and Wikipedia, they can use that understanding to improve their own research tools and help teens decide when and where it is appropriate to use specific resources.

\section{Connecting through Library Websites}

One of the most popular platforms for reaching out to teens online is a library website dedicated to young adults. In addition to involving teens in the planning of library websites, librarians must determine the purposes of websites before building them. Librarians should base this determination on what the teens want and expect from the website (Hughes-Hassell \& Miller, 2003). According to Hughes-Hassell and Miller (2003), teen library websites can provide help with school work, information about colleges and careers, and other general reference information. In addition, librarians can use websites to promote reading and library events. All of these purposes are valid, and librarians can address all of them, or some combination of them, if the librarians find they will best serve their local teens' needs.

Once librarians determine the purpose(s) of their websites, they can look more specifically at design, content, and management. While specific platforms and design software are beyond the scope of this review, individual libraries will 
need to make some basic decisions about these options. Considerations when choosing a particular type of software include librarians' knowledge of web design, the cost of particular programs, and ease of use (Horn, 2011). Librarians should also look at other leading teen library websites, such as those from the Berkeley (CA) Public Library and the Columbus (OH) Metropolitan Library, to glean effective content and design tips (Horn, 2011). Some libraries might want to consider a blog instead of (or in addition to) a standard website because it is easier to use and keep up-to-date (Hannan, 2011). For librarians who do not have web design training, a blog offers many of the same features without requiring technical expertise (Casey \& Savastinuk, 2006; Horn, 2011).

In terms of design, teen websites need to reflect the tastes of today's teens (Hughes-Hassell \& Miller, 2003). Librarians can stay current with trends and teens' preferences by looking at contemporary teen magazines and other popular teen websites (Hannan, 2011). Librarians should make sure that the design is simple, not too full of text, and easy to navigate (Bolan et al., 2007). Teens will be more likely to use a site if they can find information quickly (Agosto, Valenza, $\&$ Abbas, 2011). If teens are inundated with too many graphics or words, they are much less likely to use a website (Hilbun, 2011; Jones, et al., 2004). Since the goal is to best serve teens, the design of a website needs to enhance, not detract from, that goal.

While good design of teen library websites is essential, librarians also need to consider the substance of the websites. The content on library websites must be comprehensive. For example, the websites need to include links to the libraries' subscription databases (Hilbun, 2011). In order to get teens to use these databases, librarians should annotate the links so that teens will understand what the various databases can do for them (Jones et al., 2004). Librarians can make suggestions about how to choose between databases based on the particular research teens are trying to do.

Libraries should consider including "homework helper" services on their websites (Agosto, 2007, p. 60). Since many teens are students, school and homework are important to them. Sometimes this homework help may direct students to appropriate research tools, but having librarians available online to help teens is also important. Libraries should consider having some form of "Ask a Librarian" available to teens (Hannan, 2011). Teen librarians could answer questions via email, instant message, or text message (Bolan et al., 2007). For a successful model of these services, librarians can look to the Public Library of Charlotte and Mecklenburg County in North Carolina, where librarians use these services. The librarians believe the services are essential in part because they help teens who "feel too intimidated to walk into a library and approach a librarian at a reference desk with a question" (Summers, Pierson, Higgins, \& Woodring, 2011, p. 157). By providing these services, librarians help teens find quality 
information and also help teens develop connections to the library and the librarians.

Libraries' teen websites should also provide information about opportunities available to teens at the library. The websites can include information about special teen activities or how teens can get involved with volunteering or teen advisory boards (Hilbun, 2011). Librarians should also include photos taken at some of the libraries' teen events (Bolan et al., 2007), with appropriate permissions. Librarians can create a photo stream using a site like Flickr and have it appear on library web pages or blogs (Summers et al., 2011). Online book clubs are another avenue librarians could explore that would connect teens to each other while promoting reading (Hilbun, 2011). An additional way to connect teens to the library would be to link teen websites to the main library's web page and to any events held for the general public (Nowak, 2011). Librarians should also realize that parents of their teen patrons might use the teen-focused websites and should consider including resources that could help those parents (Horn, 2011).

Although libraries' teen websites will often focus on what the libraries themselves have to offer, they should also provide access to information beyond the library; doing so will increase the libraries' usefulness to teens. Librarians need to research what other websites teens might find interesting and help connect teens to those sites as appropriate. Librarians should select sites based on "the visual appeal of the site, ease of navigation, currency and accuracy of information, and credibility of the Website author" (Hughes-Hassell \& Miller, 2003 , p. 150). These may be sites that deal with issues such as "sexuality, sex education and teen pregnancy, teen violence, and suicide" (Jones et al., 2004, p. 280) as well as local resources and sites teens might not discover otherwise (Hilbun, 2011; Jones et al., 2004).

Library websites can also help teens connect directly to their favorite authors through links to authors' blogs, websites, or social networking pages (Beaman, 2006; Hamilton, 2009). By helping facilitate direct communication with the authors of the books teens are reading, librarians enhance teens' experiences with those books and with reading in general (Hamilton, 2009). In addition, library websites should connect teens to websites that focus on current young adult literature, such as YAContemps (www.thecontemps.com), readergirlz (www.readergirlz.com), Reading Rants! (www.readingrants.org), and Guys Lit Wire (http://guyslitwire.com) (Valenza \& Stephens, 2012). Librarians can also provide connections to "fan fiction" sites where students can read and write about popular books (Braun, 2011; Burns, 2011). In creating these links, librarians need to verify that all linked websites can actually be accessed from computers in the libraries. If the library computers have filters, teens may not be able to use some of the sites (Jones et al., 2004). 
Librarians also must move beyond reference information and include social and recreational opportunities on their websites, to address the primary reason that teens go online (socializing) and so that the teens will return to the library sites once their immediate information needs have been met (HughesHassell \& Miller, 2003). Some possible recreational links to include are those related to hobbies, popular television shows, movies, and online magazines (Agosto, 2007). Teens love to do surveys, polls, and quizzes online, so libraries could provide their own surveys or links to those already created by others (Rapacki, 2011).

Libraries should also "create a place for teens to submit their own writing, including reviews of books, Websites, video games, and computer games" (Jones et al., 2004, p. 280). In addition to space for sharing their writing, libraries can offer teens a place to share other information they create. Teens should have a place to share some of the digital projects they create in the library's teen area. For example, librarians can post links to professional book trailers and host contests that encourage teens to create their own book trailers and share them online (Hilbun, 2011; Horn, 2011). Providing an opportunity for teens to share their creative work online helps teens develop their voices and gives them an audience for their work. This sharing also strengthens the connection between teen patrons and libraries. When libraries include "opportunities for fun and relaxation, and outlets for creativity, [they] are supporting healthy adolescent development" (Hughes-Hassell \& Miller, 2003, p. 152), one of the goals of library service to teens.

\section{Connecting on Social Networking Sites}

Of course, traditional, library-hosted websites are important to libraries' services to teens, but libraries should also maintain a presence on social networking sites where teens congregate. Social networking sites are websites that create a community of users who connect by sharing information about themselves and reading each other's posts/pages (Agosto \& Abbas, 2009). By linking library websites and social networking sites, libraries "offer increased online access points and ... offer users multiple ways to interact online with their libraries" (Agosto \& Abbas, 2009, p. 35). While some librarians might be hesitant to enter into the world of social networking, they must consider the potential positive aspects. In their comprehensive article, "Teens and Social Networking: How Public Libraries are Responding to the Latest Online Trend," Agosto and Abbas (2009) identify three major benefits: "broadening the reach of young adult services," "supporting adolescents' healthy social development," and "promoting teens' online safety" (pp. 34-35). 
Teens are immersed in social media (Lenhart, Purcell, Smith, \& Zickuhr, 2010; "Social Media, Social Life," 2012). According to recent research, "90\% of all American teens have used social media, three-quarters of them have a social networking site, and nearly one in three teens visits their social networking profile several times a day or more" ("Social Media, Social Life," 2012, p. 7). The appeal of these sites to teens is obvious: they support teens' innate need for socialization and the desire to belong to a group (Lamb \& Johnson, 2006). In order to remain current and be in touch with teens, libraries must reach teens on social networking sites where they spend time. Although teens are using these sites "mainly to further preexisting relationships with known friends" (Agosto \& Abbas, 2009, p. $33)$, teens can also reach out and connect with others, including librarians.

Librarians will have to consider which of the available social networking sites they are going to use and how to use them. As when creating websites or inhouse library services, librarians need to pay attention to what teens want and determine the library's purpose for establishing a social networking presence (Horn, 2011). Many librarians and researchers are beginning to see the potential of using social networking sites to reach patrons and are developing best practices they can share. For librarians unsure where to start, YALSA offers a toolkit on its website ("Teens \& Social Media," 2011). This toolkit has an overview of social media, offers examples of ways to incorporate these services into existing young adult services, and offers suggestions on how to teach legislators, community members, and teen patrons about the benefits of social networking.

There are a variety of ways to use each of these sites. Librarians can post photos of new books, announce library events, and share a virtual tour of the library's teen area (Agosto \& Abbas, 2009). Librarians can also use these sites to elicit input from teen patrons and connect users to main library websites (Bolan et al., 2007). Since most of the social networking sites are based on some concept of adding "friends" or "following" users, librarians will have to consider who they will add as friends on these sites (Reynolds, 2011). Most librarians who are using social networks feel they need to friend their patrons, because if they do not, "it defeats the purpose of social networking sites" (Rapacki, 2011, p. 34).

For teens, the popularity of social networking sites changes quickly. Today's teens are using a variety of sites including Facebook, MySpace, Twitter, and Tumblr (Hardacre, 2010; Harris, 2006; Matteson; 2011). While the formatting and language of these sites are different, they all offer their users the same thing: connections. Facebook is currently the most popular social networking site for teens (Agosto \& Abbas, 2011; "Social Media, Social Life," 2012). Therefore, an in-depth look at Facebook can serve as a model for how to use social networking sites to connect with teen patrons. Librarians need to decide if they will create a teen-focused Facebook page or a profile (Horn, 2011). If a library creates a Facebook page, other Facebook users can "like" the page. These pages are public 
and are like advertisements for libraries' teen services (Horn, 2011). A profile is a more personal approach that libraries can use to create events, post updates, and interact on an individual basis with their friends (Horn, 2011). Being friends with teen patrons allows librarians the option of responding directly to teens" "walls" and learning about their interests and needs from the teens' own profile pages (Miller \& Jensen, 2007).

Teen librarians can use their Facebook profiles to share some of the same information they share on their websites, including new books, library events, new resources, contact information, and library hours (Miller \& Jensen, 2007). In addition to rebroadcasting information found elsewhere, Facebook and other social networking sites allow users to "tag" other users when posting news or photos (Agosto et al., 2011). Librarians can use this feature to further their connections with teens by tagging their teen patrons in library posts or photos, thereby increasing the library's visibility on those patrons' pages. Friends of those patrons can also see the library's posts and photos and may become interested in library activities. An important point about using social networking sites like Facebook is to make sure librarians update them frequently (Burns, 2011; Miller \& Jensen, 2007). When a user updates his or her "status," any updates become more prominent on friends' pages (Miller \& Jensen, 2007). Teens, like other users of social networking sites, are more likely to read information that is put in front of them (Agosto et al., 2011).

Twitter is another popular social network librarians should consider using. School librarian Buffy Hamilton (2009) explains that, "Twitter is a social network that asks the question 'What are you doing?' in 140 characters or less" (p. 14). Twitter also allows its users to tag names, ideas, and people, so that users can follow topics they find interesting. Publishers are already using Twitter to communicate with readers about upcoming events (Hamilton, 2009). Libraries could use Twitter in similar ways, such as announcing library events and new books and tagging book titles or authors (Hilbun, 2011). Another way libraries could promote reading would be to "post a compelling sentence from a new book for teens a few times a week on Twitter. . . . [and] add a link to the e-catalog" (Braun, 2011, p. 29). In an effort to provide comprehensive service, libraries should connect their Twitter accounts to their other social networking sites and library websites (Reynolds, 2011). In a comparison of various social networking sites and their appeal to teens, Reynolds (2011) asserts that "Twitter is the ultimate in electronic instant social gratification and perhaps has the most potential for engaging teens" (p. 53). While teens are currently using Twitter, librarians must regularly talk to and be ready to consider new sites, like Tumblr, which is a blog platform with social networking features (Matteson, 2011).

Several social networking sites actually focus on book sharing, including LibraryThing, Shelfari, and Goodreads. Libraries should consider using at least 
one of these sites in conjunction with their regular websites and other social networks. Young adult librarians can set up their own accounts or help direct teens to groups that already exist on these sites (Hilbun, 2011). Book sharing sites are attractive to teens because users can tag and review books in addition to joining groups to talk about books (Hilbun, 2011). Librarians can use these sites to share books new to the library and then make sure this information is displayed on their other online platforms though a widget or hyperlink (Horn, 2011).

One key component of effectively using websites and social networking sites is helping teens find the sites. Regardless of how skillfully planned or how teen-friendly a site seems, if teens do not visit the site, it is not accomplishing its goal. Librarians need to make sure the sites are easy to use and that teens know the sites exist (Hilbun, 2011). Public librarians should reach out to local schools to find ways to advertise their sites to students, such as through school newsletters, school websites, posters, and signs (Hilbun, 2011). Today's teens are targets of more media and advertising than any other generation, so marketing should be "authentic, funny, smart, and slick" (Goodstein, 2007, p. 153). In addition to sharing information in schools, libraries can seek out other community organizations that service teens and advertise with these organizations as well (Bishop \& Bauer, 2002).

Once librarians establish teen websites and connect with teen followers, they must make time to keep the sites updated. Today's teens expect their information to be current, so no matter which platform librarians choose, they must have a steady stream of information and regularly update their posts (Hannan, 2011). Librarians also need to frequently check all links to ensure that they connect teens to active websites, so that teens are not frustrated by broken links (Hughes-Hassell \& Miller, 2003). In addition, librarians must consistently look for teen input and use that feedback to help determine what changes or updates need to be made (Casey \& Savastinuk, 2006; Shay, 2011). Librarians should not be afraid to change tactics, platforms, or sites if what they are using is not working and/or if teens are pointing them in a different direction (Summers et al., 2011). Librarians must also spend time staying informed about the latest trends and technology issues by reading current blogs and websites (Kho, 2011). To ensure success, librarians need support from library administrators and should recognize that they may have to give up some duties they performed in the past to make room for these new online services to their teens (Kho, 2011). If libraries are using multiple platforms, all of these tasks become more time-consuming. However, this is time well spent because using a variety of platforms is essential for successfully reaching and serving today's teens.

\section{Connecting through Mobile Devices and E-readers}


Technology changes quickly, and mobile devices are at the forefront of this change. While these devices have been around for a number of years, their usage among teens has grown dramatically. According to a Pew Internet study, $77 \%$ of teens ages 12-17 own a cell phone, and $87 \%$ of older teens (ages 14-17) own a cell phone (Lenhart, 2012). An update to this survey reveals that " $66 \%$ of those ages 18-29 own smart phones" (Raine, 2012, p. 1). Teens primarily use their phones for text messaging and access to the Internet. Teens do not view these phones as toys, but rather as some of the most convenient tools to help them communicate with friends and family (Agosto et al., 2011). As one article noted, "far from being a source of isolation, the teen's phone is a tether to loved ones; it is a personal object, a crucial connection" (Marwick \& Boyd, 2012, n.p.)

Libraries need to find ways to tap into this technology. Currently, "among all the forms of digital communication, texting is the most ubiquitous among teenagers" ("Social Media, Social Life," 2012, p. 17). Some libraries are already using text messaging to communicate with teens about library events and overdue book notices (Hannan, 2011; Hardacre, 2010). Teens should be able to access library resources via their cell phones and might want to contact their librarians through a "text-a-librarian" service (Agosto et al., 2011). In fact in regard to mobile access, a recent Pew Internet survey found that " $13 \%$ of those ages 16 and older have visited library websites or otherwise accessed library services by mobile device" (Rainie, Zickuhr, \& Duggan, 2012, p. 2). Librarians who want to reach more teens might even consider creating mobile applications that will allow teens to gain access to library services (Hannan, 2011). Librarians need to be aware that teens are reading more on their mobile devices (Zickuhr, Rainie, Purcell, Madden, \& Brenner, 2012), so libraries should find ways to support this reading. Despite the prevalence of cell phones, librarians must be mindful that not all teens have access to mobile technology and that libraries, therefore, need to provide access to services in multiple ways (Agosto, et al., 2011).

Libraries must also decide how to best utilize other technologies that directly involve reading, like e-readers, e-books, and social reading applications. According to the Association of American Publishers, "as of February 2011, 'US publishers sold more e-books than they did books in any other format, including paperbacks and hardcovers"' (Braun, 2011, p. 27). Teen e-book sales are becoming a larger portion of those sales, possibly as much as twenty percent of all sales (Braun, 2011). As many as one third of children and teens have indicated they would read more if they had access to e-books (Lamb \& Johnson, 2011). Libraries are responding to these sentiments by maintaining growing e-book collections. Approximately 13,000 libraries, mostly in the United States, are already using OverDrive, a program which allows users to put e-books on ereaders, tablets, and some mobile phones (Springen, 2011). From 2010 to 2011 the number of young adult e-books checked out using OverDrive doubled from 
two million to four million (Springen, 2012). The demand for e-books for teens is clear, and librarians need to be able to meet that demand. Teen patrons expect young adult librarians to be knowledgeable about the various e-reading devices teens use, so libraries should "provide a few e-readers to staff members to allow them to play with the devices and build expertise" (Kho, 2011, p. 52).

Teen librarians will face challenges in managing the e-collection and making it accessible to teens (Braun, 2011). Unlike traditional book collections, the e-book collection is not visible inside the library. As a result, librarians need to take a more proactive role in searching the e-book databases and monitoring circulation and hold numbers (Braun, 2011). Libraries should also help bridge the gap between those teens who have access to e-readers or other mobile devices and those who do not. Libraries should offer teens and other patrons e-readers to check out (Springen, 2012). According to a recent Pew Internet study, 60\% of those ages 16-24 who do not currently borrow e-books from libraries say they would borrow pre-loaded e-readers if their library offered that service (Zickuhr, et al., 2012, p. 15). Libraries need to consider having e-readers available to teens and should advertise their availability through the library websites and social networking sites.

Another interesting aspect of e-books is the possibility for social reading; "with new e-reading apps such as Copia and Inkling, for example, it is possible to interact with others while reading an e-book" (Braun, 2011, p. 29). With Copia, users can track the books they have read, read new books, make notes while reading, and share those notes with other readers ("Copia," 2010). Librarians should explore the possibilities for these new social types of e-reading so they can capitalize on teens' desires to socialize and to use technology.

\section{Conclusion: Connecting in the Future}

As demonstrated in this literature review, effectively connecting with teens occurs in a variety of ways and through a variety of media, often involving technology. Public libraries can lay a foundation for making deeper connections with teens by making personal connections with teens in their communities. In addition to establishing in-person connections, libraries can take their services online where they can benefit from teens' interest in technology. With input from teens, libraries can design, develop, and manage their websites to better serve all teens. Libraries can also use currently popular social networking sites, as well as mobile devices, to engage teens and serve their library needs.

As technology continues to change, the issues librarians must consider will change as well. In terms of in-house library technology, further study is necessary to determine how libraries can best provide teens with access to technology while addressing concerns about Internet safety and Internet filters 
(Lamb \& Johnson, 2011). Libraries will need to periodically update their Internet use policies for all patrons, including teens (Jones, et al., 2004). These policies should consider teens' interests, especially those involving social networking and emerging media. Public libraries should reach out to high school libraries and find ways to work together to help teens become competent researchers and responsible digital citizens. Also, librarians must determine the best ways to fund teen services. This includes funding the hiring and training of specialized young adult librarians as well as funding the purchase of suitable technology. The technology should not only support teens' research needs, but also their friendship-driven and interest-driven needs. Librarians should consult YALSA's guide "Speaking Up for Library Services to Teens" for suggestions on how to advocate for teens in their local communities ("Speaking Up," 2011). Librarians must consider what type of technology hardware and software they will provide for teens at the library. They must also make wireless access available to teens who want to bring their own laptops and tablets to the library.

Technology and the Internet are constantly changing. To be successful in the future, librarians and researchers should stay current with advances and trends. Librarians should consider teens' love of photos, music, and videos and find ways to incorporate these into their library services. Two social networking sites to study are Pinterest and Instagram; the number of teen and adult users on both of these sites is growing rapidly. Teens also enjoy watching and posting videos on YouTube, so libraries should consider ways to share information from the library on this site. Many of today's teens are using their mobile phones and tablets to go online, take pictures and videos, and listen to music. More research should be done to determine how libraries can incorporate these mobile trends into teen library services. Libraries should also investigate using video conferencing tools, such as Skype, to reach out to teens. Libraries could use this technology to help connect teens not only to the library, but also to other teens and authors. By embracing changing technology and being willing to adapt, public libraries can continue to play a vital role in the lives of today's teens. Libraries should explore these issues more fully and tailor services to fit the specific needs of their teens. In doing so, libraries will truly connect with teens and support their development into successful adults while at the same time helping them become lifelong users and supporters of public libraries.

\section{References}

Agosto, D. (2007). Why do teens use libraries? Results of a public library use survey. Public Libraries, 46(3), 55-62. 
Agosto, D. E., \& Abbas, J. (2009). Teens and social networking: How public libraries are responding to the latest online trend. Public Libraries, 48(3), 32-37.

Agosto, D. E., \& Abbas, J. (2011). Teens, libraries, and social networking: What librarians need to know. [EBL eBook version]. Retrieved from http://reader.eblib.com.libaccess.sjlibrary.org

Agosto, D. E., Valenza, J. K., \& Abbas, J. (2011). Looking closely at teens' use of social networks: What do high school seniors do online? In D. E. Agosto \& J. Abbas (Eds.), Teens, libraries, and social networking: What librarians need to know (pp. 13-27) [EBL eBook version]. Retrieved from http://reader.eblib.com.libaccess.sjlibrary.org

Ayar, C. (2009). Making the best of it: YA librarians share how they're coping in a tough economy. Young Adult Library Services, 8(1), 31-32.

Beaman, A. (2006). How technology is enhancing the pleasure reading experience for teens. Knowledge Quest, 35(1), 30-33.

Bergson-Michelson, T. (2012, March 20). Building good search skills: What students need to know. MindShift. Retrieved December 6, 2012, from http://blogs.kqed.org/mindshift/2012/03/building-good-search-skills-whatstudents-need-to-know/

Bernier, A. (2009). A space for myself to go: Early patterns in small YA spaces. Public Libraries, 48(5), 33-47.

Bishop, K., \& Bauer, P. (2002). Attracting young adults to public libraries: Frances henne/yalsa/voya research grant results. Journal of Youth Services in Libraries, 15(2), 36-44.

Bolan, K., Canada, M., \& Cullin, R. (2007). Web, library, and teen services 2.0. Young Adult Library Services, 5(2), 40-43.

Bourke, C. (2010). Library youth spaces vs youth friendly libraries: How to make the most of what you have. Australasian Public Libraries and Information Services (APLIS), 23(3), 98-102.

Braun, L. W. (2011). Now is the time: E-books, teens, and libraries. Young Adult Library Services, 9(4), 27-30. 
Burns, E. (2011). Fandom as a form of social networking. In D. E. Agosto \& J. Abbas (Eds.), Teens, libraries, and social networking: What librarians need to know (pp. 115-131) [EBL eBook version]. Retrieved from http://reader.eblib.com.libaccess.sjlibrary.org

Casey, M., \& Savastinuk, L. (2006). Library PR 2.0. Library Journal, 131(14), 40-42.

Comito, L., \& Escobedo, F. (2011). Teens as advocates. Young Adult Library Services, 10(1), 16-17.

Copia social eReading platform goes live. (2010, Nov 22). PR Newswire, pp. n/a. http://search.proquest.com/docview/807643536?accountid=10043

Couri, S. (2011). Summer library club taking risks, finding rewards. Young Adult Library Services, 10(1), 18-20.

Danforth, L. (2011). Gaming: Let's talk. Library Journal, 136(15), 48.

Evanhart, N., \& Valenza, J. (2004). Internet-savvy students and their schools. Knowledge Quest, 32(4), 50-55.

Flowers, S. (2008). Guidelines for library services to teens. Young Adult Library Services, 6(3), 4-7.

Goodstein, A. (2007). Totally wired: What teens and tweens are really doing online. New York: Saint Martin's Griffin.

Hamilton, B. (2009). Young adult literature 2.0. Library Media Connection, 28(3), 14-15.

Hannan, A. (2011). Communication 101: We have made contacts with teens. Australasian Public Libraries and Information Services (APLIS), 24(1), 32-38.

Hardacre, M. (2010). Teens talk tech. Young Adult Library Services, 8(2), 29-30.

Harris, C. (2006). MySpace can be our space. School Library Journal, 52(5), 30.

Hilbun, J. (2011). Using social networking to connect teens with young adult literature. Public Libraries, 50(3), 42-49. 
Hill, R. (2010). The world of multitasking teens: How library programming is changing to meet these needs. Young Adult Library Services, 8(4), 33-36.

Horn, L. (2011). Online marketing strategies for reaching today's teens. Young Adult Library Services, 9(2), 24-27.

Houston, N. (2011). Building a foundation for teen services. Young Adult Library Services, 9(2), 6-9.

Howard, V. (2011). What do young teens think about the public library?. Library Quarterly, 81(3), 321-344.

Hughes-Hassell, S., \& Miller, E. (2003). Public library web sites for young adults: Meeting the needs of today's teens online. Library \& Information Science Research (07408188), 25(2), 143-156.

Ito, M., Horst, H., Bittani, M., boyd, d., Herr-Stephenson, B., Lange, P. G., Pascoe, C.J., \& Robinson, L. (2008, Nov.). Living and learning with new media: Summary of findings from the Digital Youth Project (Rep.). Retrieved December 1, 2012, from MacArthur Foundation website: http://www.macfound.org/media/article_pdfs/DML_ETHNOG_WHITEP APER_1.PDF

Ito, M., Baumer, S., Bittani, M., boyd, d., Cody, R., Herr-Stephenson, B., Horst, H. A., Lange, P.G., Mahendran, D., Martinez, K.Z., Pascoe, C.J., Perkel, D., Robinson, L., Sims, C., \& Tripp, L. (2010). Hanging out, messing around, and geeking out: Kids living and learning with new media. The MIT Press. Retrieved November 30, 2012, from https://mitpress.mit.edu/books/hanging-out-messing-around-and-geekingout

Jacobs, A. (2012, Feb. 27). Google-trained minds can't deal with terrible research database UI. The Atlantic. Retrieved December 6, 2012, from http://www.theatlantic.com/technology/archive/2012/02/google-trainedminds-cant-deal-with-terrible-research-database-ui/253641/

Jones, P. (2003). To the teen core. School Library Journal, 49(3), 48.

Jones, P., Gorman, M., \& Suellentrop, T. (2004). Connecting young adults and libraries: A how-to-do-it manual for librarians (3rd ed.). New York: NealSchuman Publishers. 
Joseph, M. (2010). An exquisite paradox: Making teens and young adults welcome in public libraries. Australasian Public Libraries and Information Services (APLIS), 23(3), 107-110.

Kho, N. D. (2011). Social media in libraries keys to deeper engagement. Information Today, 28(6), 1-32. http://search.proquest.com/docview/870511714? accountid=10043

Klipper, B. (2011). Funding problems? Your teens can make a difference. Young Adult Library Services, 9(4), 36-37.

Lamb, A. (2011). Social networking: Teen rights, responsibilities, and legal issues. In D. E. Agosto \& J. Abbas (Eds.), Teens, libraries, and social networking: What librarians need to know (pp. 77-95) [EBL eBook version]. Retrieved from http://reader.eblib.com.libaccess.sjlibrary.org

Lamb, A., \& Johnson, L. (2006). Want to be my "friend"? What you need to know about social technologies. Teacher Librarian, 34(1), 55-57.

Lamb, A., \& Johnson, L. (2011). Nurturing a new breed of reader: Five real-world issues. Teacher Librarian, 39(1), 56-63.

Lenhart, A. (2009, April 10). Teens and social media: An overview. Pew Research Center's Internet \& American Life Project. Retrieved April 13, 2012 from http://isites.harvard.edu/fs/docs/icb.topic786630.files/Teens Social Media and Health - NYPH Dept Pew Internet.pdf

Lenhart, A. (2012, March 19). Teens, smartphones \& texting. Pew Research Center's Internet \& American Life Project. Retrieved December 1, 2012 from http://www.pewinternet.org/ /media//Files/Reports/2012/PIP_Teens_Sm artphones_and_Texting.pdf

Lenhart, A., Madden, M., Smith, A., Purcell, K., Zickuhr, K., \& Rainie, L. (2011, Nov. 9). Teens, kindness, and cruelty on social network sites. Pew Research Center's Internet \& American Life Project. Retrieved December 4, 2012, from http://pewinternet.org/ /media//Files/Reports/2011/PIP_Teens_Kindness _Cruelty_SNS_Report_Nov_2011_FINAL_110711.pdf

Lenhart, A., Purcell, K., Smith, A., \& Zickuhr, K. (2010, Feb. 3). Social media and young adults. Pew Research Center's Internet \& American Life 
Project. Retrieved March 11, 2012, from

http://pewinternet.org/Reports/2010/Social-Media-and-Young-

Adults.aspx

Long, S. (2005). What's new in libraries? Digital natives: If you aren't one, get to know one. New Library World, 106(3/4), 187-189.

Ludwig, S. (2011). Teen tech camp. Young Adult Library Services, 9(2), 31-33.

Macchion, F., \& Savic, N. (2011). Youth: An exchange of ideas for public libraries. Australasian Public Libraries and Information Services (APLIS), 24(1), 17-22.

Marwick, A., \& boyd, d. (2012, May 20). Teens text more than adults, but they're still just teens. The Daily Beast. Retrieved December 1, 2012, from http://www.thedailybeast.com/newsweek/2012/05/20/teens-text-morethan-adults-but-they-re-still-just-teens.html

Matteson, A. (2011). Do you Tumble? Tumblr could change the way you blog. School Library Monthly, 27(5), 54-56.

Miller, S., \& Jensen, L. A. (2007). Connecting and communicating with students on Facebook. Computers In Libraries, 27(8), 18-22.

Neiburger, E. (2007). Gamers-- in the library?!: The why, what, and how of videogame tournaments for all ages. Chicago: American Library Association.

Nicholson, S. (2008). Reframing gaming. American Libraries, 39(7), 50-51.

Nowak, K. (2011). Serving teens in the public library. Kentucky Libraries, 75(3), 6-11.

Peowski, L. (2010). Where are all the teens? Engaging and empowering them online. Young Adult Library Services, 8(2), 26-28.

Purcell, K., Raine, L., Heaps, A., Buchanan, J., Friedrich, L., Jacklin, A., Chen, C., \& Zickuhr, K. (2012, November 1). How teens do research in the digital world. Pew Research Center's Internet \& American Life Project. Retrieved November 28, 2012, from http://pewinternet.org/ /media//Files/Reports/2012/PIP_TeacherSurveyR 
eportWithMethodology110112.pdf

Prensky, M. (2001). Digital natives, digital immigrants. On the Horizon, 9(5), 16. Retrieved from http://www.marcprensky.com/writing/

Raine, L. (2012, Sep. 11). Smartphone ownership update: September 2012. Pew Research Center's Internet \& American Life Project. Retrieved December 4, 2012, from http://www.pewinternet.org/ /media//Files/Reports/2012/PIP_Smartphon es_Sept $12 \% 209 \% 2010 \% 2012 . p d f$

Raine, L., Zickuhr, K., \& Duggan, M. (2012, Dec. 31). Mobile connections to libraries. Pew Research Center's Internet \& American Life Project. Retrieved January 1, 2013, from http://libraries.pewinternet.org/files/legacypdf/PIP_MobileConnectionsToLibraries.pdf

Rapacki, S. (2007). Social networking sites: Why teens need places like MySpace. Young Adult Library Services, 5(2), 28-30.

Rapacki, S. (2011). How social networking sites aid in teen development. In D. E. Agosto \& J. Abbas (Eds.), Teens, libraries, and social networking : What librarians need to know (pp. 29-38) [EBL eBook version]. Retrieved from http://reader.eblib.com.libaccess.sjlibrary.org

Reynolds, S. D. (2011). If you build it, will they come? A comparison of social networking utilities. In D. E. Agosto \& J. Abbas (Eds.), Teens, libraries, and social networking : What librarians need to know (pp. 49-58) [EBL eBook version]. Retrieved from http://reader.eblib.com.libaccess.sjlibrary.org

Shay, C. (2011). The twilight zone: Bringing youth into libraries. Australasian Public Libraries and Information Services (APLIS), 24(1), 42-46.

Snowball, C. (2008). Teenagers talking about reading and libraries. Australian Academic \& Research Libraries, 39(2), 106-118.

Social media, social life: How teens view their digital lives. A Common Sense Media Research Study. (2012). Common Sense Media. Retrieved November 30, 2012, from 
http://www.commonsensemedia.org/research/social-media-social-life/keyfinding-1\%3A-teens-are-avid\%2C-daily-users-of-social-media

Speaking up for library services to teens. (2011, Nov. 15). Young Adult Library Services Association. Retrieved February 26, 2012, from www.ala.org/yalsa/sites/ala.org.yalsa/files/content/advocacy_final.pdf

Springen, K. (2011). Reaching the e-teen. Publishers Weekly, 258(8), 21-24.

Springen, K. (2012). Are teens embracing e-books? Publishers Weekly, 259(8), 20-23.

Sullivan, M. (2011). Walls can talk . . but are they speaking to teens?. Teacher Librarian, 39(2), 13-15.

Summers, H., Pierson, R., Higgins, C., \& Woodring, R. (2011). Pages, profiles, and podcasts: How Charlotte Mecklenberg Library engages teens through social networking. In D. E. Agosto \& J. Abbas (Eds.), Teens, libraries, and social networking: What librarians need to know (pp. 151-167) [EBL eBook version]. Retrieved from http://reader.eblib.com.libaccess.sjlibrary.org

Teens \& social media in schools \& public libraries: a toolkit for librarians \& library workers. (2011). Young Adult Library Services Association. Retrieved February 26, 2012 from http://www.ala.org/yalsa/sites/ala.org.yalsa/files/content/professionaltools/ Handouts/sn_toolkit11.pdf

Teens' love-hate relationships with reading. (2010). School Library Journal, $56(11), 35$.

Vaillancourt, R. J. (2000). Bare bones young adult services: Tips for public library generalists. Chicago, Ill: American Library Association.

Valenza, J. (2011). Fully loaded. School Library Journal, 57(1), 36-38.

Valenza, J. K., \& Stephens, W. (2012). Reading remixed. Educational Leadership, 69(6), 75-78.

Van Lewen, K. (2009). Ahead of the game: How the Public Library of Charlotte and Mecklenburg County (PLCMC) and their partners threw out all the 
old ideas of what a "youth center" should look like. North Carolina Libraries (Online), 67(2), 33-35.

Walter, V. A., \& Meyers, E. (2003). Teens \& libraries: Getting it right. Chicago: American Library Association.

Zickuhr, K., Rainie, L., Purcell, K., Madden, M., \& Brenner, J. (2012, October 23). Younger Americans' reading and library habits. Pew Research Center's Internet \& American Life Project. Retrieved November 17, 2012, from http://libraries.pewinternet.org/files/legacypdf/PIP_YoungerLibraryPatrons.pdf 